\title{
Urgency Formation of Legal Service Institutions and Teacher Protection
}

\author{
Yenny Aman Serah ${ }^{1}$, R Setiawati ${ }^{2}$ \\ ${ }^{1,2}$ Faculty of Law, Universitas Panca Bhakti Pontianak \\ 1yenny.upb@gmail.com, ${ }^{2}$ rini090366@gmail.com
}

\begin{abstract}
The reality of the still widespread cases of criminalization of teachers by parents of students or families in several regions should be an important concern to develop policies to provide protection for teachers. This study aims to reveal what policies need to be developed in an effort to provide legal protection to teachers from criminalization cases. Through socio legal research methods through data collection tools for interviews and focused discussions, the results of the study revealed that the criminalization of teachers in carrying out their professional duties still occurred, especially when the research was conducted in Pontianak City, West Kalimantan Province. Based on the facts of the problems faced in overcoming the teacher criminalization case there is no clear mechanism in handling it, so that each party takes its own steps in its resolution. Therefore we need a strategic step in the form of the importance of regulating a policy to establish a legal service institution and teacher protection in order to realize equitable teacher protection.
\end{abstract}

Keywords: Criminalization of Teachers, Legal Services and Teacher Protection Policy

\section{INTRODUCTION}

Ing ngarso sun tulodo ing madya mangun karso tut wuri handayani is the soul and spirit that is always held by teachers in carrying out their educational tasks, so that the motto is an example and discipline for students [1]. Teacher profession as hero without service is a very noble profession, because teachers can shape the character of their students. The teacher is the executor of the learning process and runs the education, so the community is very much hopeful of the teacher, so running the teaching profession is not easy, because the teacher is a very vital profession in the world of education.[2]

Judging from the position, function and role in National Development in the field of education, the teacher is a dignified profession with the task of teaching, guiding, evaluating and educating students. In carrying out their roles and duties constantly interacting with students, parents of students, the community, so it is not uncommon for teachers to be professionally responsible beyond what is their responsibility.[3]. Thus, efforts are needed to encourage and empower teachers as professional educators to build a strong education towards a higher quality.[4] In fact, a teacher has multiple roles that are very important in educational success. The teacher is the spearhead of the success of education at the operational level. Teachers are also always at the forefront of education, dealing directly with students through an instructional interaction process as a vehicle for student learning in the nuances of education.[5] 
But empirically, the challenge facing the education world is the apathy of teachers in carrying out their educational tasks, the fact which is influenced by the outbreak of cases of teacher criminalization by parents / families. Cases of criminalization against teachers have disturbed the concentration of teachers in teaching. The reality in Pontianak on March 8, 2018 there was violence against one of the teachers. NK, a teacher from the East Pontianak Middle School, was persecuted by his own students until he fainted and was hospitalized because he suffered an ear injury.

The incident began because the perpetrator was annoyed when he was reprimanded using a cellphone while learning material. The case certainly had an impact on the perceptions and attitudes of other teachers because they were able to make teachers in fear because they were afraid when giving disciplinary punishment to students instead of getting vigilante action from students or parents of students or being reported to the police for alleged violations child rights. As a result, many teachers are apathetic. Teachers come to schools that are important to teach, and when there are students who violate school rules do not dare to take action for fear of being reported to the Police. This reality raises the question of the extent to which teacher protection is implemented.

Teacher protection has been regulated in various laws and regulations. The obligation to provide legal protection to teachers in carrying out their professional duties, especially placed on the government, both the central government and regional governments. The obligation begins with providing laws and regulations ranging from laws, government regulations, to regional regulations as a legal umbrella for the government and regional governments in making policies and forms of policies that are appropriate and in accordance with the rights that must be received by teachers. In particular the Pontianak City Government has ratified the Pontianak City Regional Regulation No. 7 of 2017 concerning Teacher Protection.

Article 27 This Regional Regulation contains "Implementing Regulation of this Regional Regulation must be determined no later than 1 (one) year from the enactment of this Regional Regulation". This Regional Regulation was established and promulgated on August 21, 2017. It means that implementing regulations for Pontianak City Regulation Number 7 of 2017 concerning Teacher Protection have been established. That is why, in this paper the problem will be examined under the title "Urgency of Establishing Law Services and Teacher Protection Institutions" as a mandate contained in the substance of the Pontianak City Regional Regulation norms.

Based on the description above, the problem was formulated, namely: What policies need to be developed in an effort to provide legal protection to teachers and the urgency of establishing legal service institutions and teacher protection?

\section{RESEARCH METHOD}

This study uses a sociological-juridical method, intended to understand the relationship or the relationship between legal phenomena with society. Because basically law is not only seen as a normative intensity that is independent or isoteric, but rather as a real part of the social system relating to social, cultural and other variables. Through this method, it is expected to find hidden meanings behind or the subject under study, so that they can reveal the secrets of something by collecting information in a reasonable state, using systematic, directed and accountable work methods. Not only recording things that appear explicitly, but must look at the whole phenomenon that occurs. 


\section{RESULTS AND DISCUSSION}

\subsection{Portrait of Teacher's Criminalization}

Violence that occurred in the world of education and led to the criminalization of teachers is a phenomenon and a small picture of moral degradation that occurs in society that is increasingly developing today. This condition deserves important attention considering the teacher is a figure who has a very important role in the development of students who are morally intelligent and knowledgeable. Moreover, this reality can create a fear of the teacher so that it creates more complex problems because the teacher becomes apathetic and does not apply discipline in school.[6] Violence is asignificant problem, policies have been developed to reduce bullying, yet policy implementation by educators is an essential yet difficult and complex process.[7] The crucial problem faced by teachers is when they have to give punishment to students who violate school rules and regulations. Although intended to uphold discipline, often parents and some people judge it as violating human rights or the Child Protection Act, so that they easily report the disciplinary action of teachers to the police officers because of violence against children.

The above conditions as revealed from the results of focus group discussions, the education process which should include three domains, namely attitudes, knowledge and skills become more dominant to the realm of knowledge. As a result, many children are smart but their attitudes and behavior are not good. The impact of the number of juvenile delinquency is increasing and worrying. Even in the category of crime, which of course this can not be tolerated. Schools should be a place for the character of children to grow up, and become a comfortable place for students, and parents trust the school as a place of education for their children, so that the protection of children and teachers can be realized.

However, the reality, especially in the city of Pontianak, criminalization of teachers still occurs, although if further study of the criminalization occurs the fact is there are also teachers who have not understood the conception of discipline to their students, so the actions taken go beyond emotions and lead to violence, but there are also facts where children has a behavior problem.

If reviewed, the teacher in carrying out his professional duties has a reference source in the form of legislation that can be a guideline for every teacher to know the scope of their professional rights and obligations. In Indonesia, for example, there are several laws and regulations specifically regulating the teaching profession, namely Law Number 20 of 2003 concerning the National Education System, Law Number 14 of 2005 concerning Teachers and Lecturers, and Government Regulation Number 74 of 2008 concerning Teachers, so that teachers in carrying out their professional duties should know and understand all the laws and regulations relating to their profession so that a teacher figure who has legal and professional awareness can be realized in order to realize good quality education.

However, the criminalization of the teachers mentioned above requires a special guideline to overcome them. It should be that every sentence has an educational effect. school education instills the spirit of school discipline to instill respect for rules so that students obey the rules of the rules and can feel something valuable and worthy of respect, where they are instilled only through the teacher. [8]

The law is increasing affecting the practice of education. The most likely reason a teacher or school will face legal action is in negligence where a student has been injured while under the school's protection. This may occur in a variety of settings. To satisfy the elements of the tort of negligence the student who becomes in law the plaintiff must prove that a duty of 
care was owed, that the duty was breached, by not maintaining the appropriate standard and that the injury was a reasonably foreseeable consequence of that breach of duty. It would be rare for a teacher to face criminal charges but it could happen if a teacher had an intention to harm or acted recklessly.[9]

Anticipating the rampant criminalization of these teachers, there is also a Working Guideline between the Indonesian National Police and the Indonesian Teachers Association Number: B / 53 / XII / 2012 Number: 1003 / UM / PB / XX / 2012 concerning the mechanism of handling cases and securing the teaching profession that aims that the process of legal protection to the teaching profession can be carried out as well as possible. The MoU contains work guidelines between the police of the Republic of Indonesia and the Indonesian Teachers Association regarding the mechanism for handling cases and securing the teaching profession. The background to the formation of an MoU between PGRI and the National Police is to realize legal protection for teachers in carrying out their profession.[10]

Research conducted [11] reveals the results of analysis of research data which shows that: the Agency in this case the Office of Education and Culture does not yet have a monitoring system / monitoring of violence in teaching and learning interactions in schools; so that teachers who commit violence, are caused more by the paradigm and insight of their education, that to enforce discipline must be by force. As is also the case with research findings from a portrait of the criminalization of teachers, it is more influenced by the absence of clear rules about the mechanism for handling violence that occurs in schools, so that when problems occur between teachers and students, the solution is as stated in the table. the following:

Table : Actions Taken in Resolving Violent Cases Towards or By Teachers

\begin{tabular}{|l|l|c|c|}
\hline \multirow{2}{*}{ Action } & \multicolumn{1}{c}{ Pontianak City } \\
\cline { 3 - 4 } No & \multicolumn{1}{c|}{ Quantity } & \% \\
\hline 1 & $\begin{array}{l}\text { Completed by deliberation (peaceful } \\
\text { at school) }\end{array}$ & 17 & 48.57 \\
\hline 2 & Solved by giving compensation & 1 & 2.86 \\
\hline 3 & $\begin{array}{l}\text { Completed by the Teacher } \\
\text { Proffesional Organization (PGRI) }\end{array}$ & 6 & 17,14 \\
\hline 4 & Completed through related agencies & 5 & 14.29 \\
\hline 5 & Resolved through a legal process & 2 & 5.71 \\
\hline 6 & Etc Amount & 4 & 11.43 \\
\hline
\end{tabular}

Source: Processed Field Research

The data in the table above revealed that the majority of respondents in Pontianak City a total of $17(48.57 \%)$ resolved their problems by deliberation, and there were $6(17.14 \%)$ respondents who stated they were resolved through the PGRI organization and there were also $5(14.29 \%)$ respondents delegated to the Office of Education and Culture to solve the problem, while there were $4(11.43 \%)$ stated others, including resolved privately or through social media, and there were also $2(5.71 \%)$ respondents who resolved the problem through legal channels.

When the fieldwork was conducted through a focused discussion forum even though the problem was mostly resolved amicably, at $48.57 \%$ in Pontianak City, the school revealed the need for the Government to accommodate the formation of a unit that could be a vehicle 
for resolving problems against teacher, which involved various parties involved in handling it. Because reality is found even though it is resolved peacefully, but peace here is interpreted as not being processed legally, but the parents of students still demand that teachers be given administrative sanctions in various forms by the school on the basis that the teacher has committed violence against their students, while the teacher believes that the violence was carried out in the framework of the educational process of their students. These conditions the school hopes the need for the formation of units or institutions that can be a container to solve the problem and of course can provide protection for both teachers and children.

Related to the urgency of establishing a forum that is able to handle the problem of teacher criminalization above, in fact the Pontianak City Government has regulated the Pontianak City Regional Regulation No. 7 of 2017 concerning Teacher Protection. The ratification of the Regional Regulation is based on the consideration of the need for efforts to empower and improve the quality of teachers in a planned, directed and continuous manner in order to improve the quality and accountability of education in Pontianak City that is able to face challenges in accordance with the demands of changing local, national and global lives. In addition, teachers have functions, roles and positions that are very strategic in development in the field of education so it needs to be developed as a dignified profession and get guaranteed protection in carrying out tasks.

Article 17 Regional Regulation Number 7 of 2017 concerning Teacher Protection which contains "Local Government, Education Unit, Teacher Professional Organization, parents and family and / or community in accordance with their respective authorities is responsible for providing protection to teachers in carrying out their duties in the form of a sense of security and guarantees of safety through legal, professional, occupational safety and health protection, and / or intellectual property rights.

Legal protection for teachers is done if they get acts of violence, threats, discriminatory treatment, intimidation, or unfair treatment on the part of students, parents of students, community, government, or other parties given in the form of legal consultation and legal assistance outside the court.

In order to streamline and ensure the implementation of legal protection for teachers, the Legal Service and Teacher Protection Unit was formed which should have been established a year after the Regulation was passed as stipulated in the provisions of Article 19 paragraph (4) of Regional Regulation No. 7 of 2017 concerning Teacher Protection. that further provisions regarding the formation, organizational structure, membership, budget and work mechanism of the Law Services and Teacher Protection Unit (UPHPG) are regulated by the Mayor Regulation.

\subsection{Urgency of Establishing a Law Services and Teacher Protection Unit}

According to Suharno, a policy is an action that aims at the goals proposed by a person, group or government in a particular environment in connection with certain obstacles while looking for opportunities to achieve the goals or realize the desired goals.[10]

WI Jenkis who formulated public policy as, "... a set of interrelated decisions taken by a political actor or group of actors concerning the selection of goals and the means of achieving them within a specified situation of goals and the means of achieving them within a specified situation where these decisions should, in principle, be within the power of these actors to achieve"[10]

Likewise, the formulation of policies that accommodate teacher protection. Efforts to realize legal protection for teachers are very important to be realized, to achieve [12] Realizing 
the figure of qualified teacher having profession-alism in carrying out the function and education responsibility; and Achieving teaching and learning process in schools that spawned learner who have competence in the field of science and have good character.

Both of these considerations contain legal ideals that are anchored by philosophical values, which take into account the values of worldview, awareness, local wisdom and law which include the atmosphere of mysticism and the philosophy of the Indonesian people so that they will be consistent with the legal guiding principles.

The existence of Pontianak City Regional Regulation Number 7 Year 2017 concerning Philosophy of Teacher Protection is expected to be a renewal of regional law that has a strategic position, as a foundation and adhesive for development in the region, which means the actualization of the legal function as a development engineering tool (law as a tool of social engineering), a problem solving instrument (dispute resolution) and an instrument that regulates people's behavior (social control) [13]

Sociologically, the existence of law (regional regulations) is for life together with humans. Suppose the word law is related to other things, but in the end it will always be related to the life with that human. Thus, in a nutshell it can be said that the law functions to serve and at the same time regulate life together with humans (the community). So thus that the problems concerning the law are closely related to various aspects of society. The law is not an entity independent from the world around it.

Underpinning good thinking from philosophical, sociological and juridical aspects, this research can be formulated to take implementative steps to provide legal protection for teachers in carrying out their professional duties in order to avoid all forms of threats and acts of violence, it is necessary to formulate a Regional Policy in the formulation of norms / the substance regulates among others that legal protection of teachers is carried out if they get acts of violence, threats, discriminatory treatment, intimidation, or unfair treatment on the part of students, parents of students, the community, government, or other parties. The legal protection referred to is provided in the form of access to obtain legal consultation, and legal assistance both inside and outside the court.

Implementative measures for the protection of teachers in the regional policy are important to formulate that in order to effectively and ensure the implementation of legal protection for teachers it is important to establish a Teacher Service and Legal Service Unit that has not yet been established.

This Teacher Protection and Legal Services Unit can be said to be the development of a model of teacher protection in which the institution acts as a form / organization of the organization in providing legal protection to teachers, where the container / organization consists of elements from the Regional Government, Teacher Professional Organizations, Educational Units, Officials Police, Academics and Community Institutions engaged in legal aid.

The establishment of a legal service and teacher protection institution is a very urgent matter to do and follow up because it is based on the facts discussed above, nothing has been explained in addressing the problem of teachers and students in the learning process, when the teacher seeks disciplinary questions as a form of violence and against the child, so it leads to the criminalization of the teacher. Therefore, the policy to improve the laws and regulations of the Mayor.

Efforts to encourage the establishment of Legal Services and Teacher Protection Institutions require advocacy steps that involve stakeholders, and carry out the mandate of the formulation in Article 19 paragraph (3) of Pontianak City Regional Regulation No. 7 of 2017 
concerning Teacher Protection to realize a coordinating institution that can be assigned tasks and roles, including:

a) Coordinating the prevention and handling of acts of violence, threats, discriminatory treatment, intimidation, or unfair treatment on the part of students, parents of students, community, government, or other parties towards teachers;

b) provide legal consulting services to teachers;

c) provide legal assistance services both inside and outside the court to teachers;

d) monitor the progress of implementing legal protection for teachers; and

e) carry out reporting and evaluation

\section{CONCLUSIONS}

In order to tackle the problem of the increasingly widespread criminalization of teachers, it is necessary to implement an implemented step by establishing a Legal Service and Teacher Protection Institute as outlined in the Mayor Regulation policy. The establishment of this institution is the development of a model for realizing just teacher protection, because it is a coordinating institution that involves all interested parties to solve problems in the education process, so that the teaching profession is a dignified profession for printing young people with integrity and noble character.

In order to study and formulate a model of the working mechanism of the legal service and teacher protection institutions, it is recommended that the need for further study and research involve more stakeholders to accommodate aspirations and opinions so that a draft of the Pontianak Mayor Regulation concerning the Formation of Legal Services Units / Institutions and Teacher protection which emphasizes the mechanism and process of solving problems faced by teachers who are more just.

\section{ACKNOWLEGDEMENT}

The researcher would like to thank the Directorate General of Strengthening Research and Development of the Ministry of Research, Technology and Higher Education (Kemenristekdikti) of the Republic of Indonesia for funding this research as well as all those who have helped carry out research.

\section{REFERENCES}

[1] I. Moeis, A. Rafni, and J. Indrawadi, "Otoritas Guru Dalam Konteks Pendidikan Kritis di SMA Negeri Kota Padang,” J. Pendidik. dan Kebud., vol. 16, no. 4, p. 391, 2010.

[2] E. Komara, "Perlindungan Profesi Guru di Indonesia," Mimb. Pendidik., 2016.

[3] Harun, "Perlindungan Hukum Profesi Guru Dalam Perspektif Hukum Positif," J. Law Justiceustice, vol. 1, no. 1, pp. 74-84, 2016.

[4] - Mustofa, "Upaya Pengembangan Profesionalisme Guru di Indonesia," J. Ekon. dan Pendidik., vol. 4, no. 1, pp. 76-88, 2012.

[5] R. H. Abdul Rahman Prakoso, "PROFESI GURU ATAS TINDAKAN PEMBERIAN HUKUMAN TERHADAP SISWA,” pp. 177-187.

[6] R. S. Yenny AS, "Non Penal Policies to Overcome Violence in the World of Education: a Study of Justice Perspective in Teaher Protection," vol. 1, pp. 122-131, 2019. 
[7] W. J. Hall and M. V. Chapman, "The Role of School Context in Implementing a Statewide Anti-Bullying Policy and Protecting Students," Educ. Policy, 2018.

[8] R. Setiawan, "Perlindungan Guru Yang Menjalankan Profesinya Sebagai Pendidik di Sekolah DapatDituntut Pidana Yang Dilaporkan Oleh Wali Guru," Univ. Nusant. PGRI Kediri, vol. 01, pp. 1-7, 2017.

[9] H. Newnham, "When is a teacher or school liable in negligence?," Aust. J. Teach. Educ., 2000.

[10] P. I. D. H. Sunarto, M. S. Ii, and Y. Prasetyo, "Kebijakan Perlindungan Hukum Terhadap Praktek Mengajar Guru Dari Ancaman Kriminalisasi (Studi Pada PGRI Kabupaten Ponorogo)," 2012.

[11] T. Muis, "Tindakan Kekerasan Guru Terhadap Siswa dalam Interaksi Belajar Mengajar (Studi Kasus di SMAN Surabaya)," J. Pendidik. (Teori dan Prakt., vol. 2, no. 1, p. 86, 2017.

[12] Y. As, "The Urgency of Pontianak Local Public Policy in Emboding Legal Protection Against Teacher," Int. J. Humanit. Arts Soc. Sci., vol. 3, no. 6, pp. 241-248, 2017.

[13] Y. Yusdiyanto, "Partisipasi Masyarakat Dalam Pembentukan Program Legislasi Daerah," Fiat Justisia, vol. 5, no. 2, 2014. 